\title{
ANALISIS PERBANDINGAN KINERJA KEUANGAN (STUDI KASUS PADA KOPERASI WANITA KARTINI PRAYA DAN KOPERASI WANITA KIBLAT PRAYA PERIODE 2010-2014)
}

\author{
Okta Viana ${ }^{1}$, Drs. Hermanto MBA, DBA ${ }^{2}$, Drs. H. Burhanudin, M. Si ${ }^{3}$ \\ ${ }^{l}$ Fakultas Ekonomi dan Bisnis Universitas Mataram,oktaviana@unram.ac.id \\ ${ }^{2}$ Fakultas Ekonomi dan Bisnis Universitas Mataram, hermanto57@unram.ac.id \\ ${ }^{3}$ Fakultas Ekonomidan Bisnis Universitas Mataram,_burhanudin_mtr@yahoo.com
}

\begin{abstract}
ABSTRAK
Koperasi Wanita Kartini Praya dan Koperasi Wanita Kiblat Praya merupakan koperasi yang bergerak dalam bidang jasa simpan pinjam. Laporan keuangan masing-masing koperasi menunjukkan pluktuasi nilai neraca keuangan dari tahun ke tahun, untuk itu perlu dilakukan analsisi kinerja keuangan untuk melihat faktor yang berpengaruh terhadap peningkatan ataupun penurunan kinerja keuangan kedua koperasi serta kemudian membandingkannya. Penelitian ini bertujuan untuk menganilisis perbandingan kinerja keuangan Koperasi Wanita Karitni Praya dan Koperasi Wanita Kiblat Praya ditinjau dari Analisis Rasio, Trend dan Common Size.

Jenis penelitian ini adalah penelitian komparatif, metode pengumpulan data dengan teknik dokumentasi. Data yang digunakan adalah data sekunder. Metode analaisis yang digunakan adalah analisis Rasio, Trend dan Common Size. Prosedur analisis yang digunakan adalah dengan mencari rasio keuangan Koperasi Wanita Kartini Praya dan Koperasi Wanita Kiblat Praya kemudian dianalisis menggunakan analisis Rasio, Trend dan Common Size. Selanjutnya dilakukan perbandingan dari masingmasing metode analisis untuk melihat koperasi yang lebih baik dari masing-masing metode analisis.

Hasil penelitian menunjukkan bahwa secara umum Koperasi Wanita Kartini Praya dan Koperasi Wanita Kiblat Praya memiliki kinerja keuangan yang sama jika ditinjau dari Analisis Rasio, Trend dan Common Size. Saran yang dapat diberikan kepada masing-masing koperasi adalah dengan mengefisiensikan sumber daya yang dimiliki sehingga dapat menekan biaya operasional yang ada.
\end{abstract}

Kata kunci: Kinerja Keuangan, Analisis Rasio, Analisis Trend, Analisis Common Size

\section{PENDAHULUAN}

Koperasi merupakan salah satu badan usaha yang berbadan hukum dengan usaha yang beranggotakan orang-seorang yang berorientasi menghasilkan nilai tambah yang dapat dimanfaatkan bagi peningkatan kesejahteraan anggotanya. Selain itu, koperasi juga sebagai gerakan ekonomi rakyat yang berorientasi untuk menumbuhkan partisipasi masyarakat dalam upaya memperkokoh struktur perekonomian nasional dengan demokrasi ekonomi yang berdasarkan atas asas kekeluargaan. Banyak jenis koperasi yang didasarkan pada kesamaan kegiatan dan kepentingan ekonomi anggotanya seperti Koperasi Simpan Pinjam (Koperasi Simpan Pinjam), Koperasi Konsumen, Koperasi Produksi, Koperasi Pemasaran dan Koperasi Jasa.

Koperasi Wanita Kartini Praya dan Koperasi Wanita Kiblat Praya sebagai koperasi yang berada di Kabupaten Lombok Tengah, tentunya memiliki tanggung jawab terhadap amanat Undang-Undang untuk memainkan peranan penting dalam perekonomian dan soko guru perekonomian Indonesia seperti yang telah dijelaskan sebelumnya. Untuk mewujudkan hal tersebut tentunya Koperasi Wanita Karitni Praya dan Koperasi Wanita Kiblat Praya dituntut untuk mampu secara baik dalam meningkatkan kinerja keuanganya. Kinerja keuangan koperasi merupakan cerminan seberapa jauh koperasi telah melangkah. Kajian terhadap kinerja keuangan merupakan 
faktor yang patut dipertimbangkan untuk melihat sejauh mana hasil yang didapatkan dalam menjalankan kegiatan usahanya. Koperasi mempunyai peran penting dalam tercapainya kesejahteraan bagi anggota khususnya dan masyarakat pada umumnya. Koperasi sebagai salah satu bentuk organisasi atau instansi pada umumnya memiliki tujuan tertentu yang ingin dicapai dalam usaha untuk memenuhi kepentingan para anggotanya.

Salah satu indikator untuk melihat kinerja keuangan koperasi yaitu dari hasil analisis laporan keuangannya. Pada dasarnya laporan keuangan merupakan hasil perhitungan akuntansi yang dapat digunakan untuk alat berkomunikasi antara data keuangan atau aktivitas suatu perusahaan dengan pihak-pihak yang berkepentingan dengan data atau aktivitas perusahaan tersebut, (Munawir, 2005:2). Tujuan dari analisis laporan keuangan adalah sebagai alat forecasting mengenai kondisi dan kinerja keuangan di masa mendatang. Adapun beberapa teknik yang biasanya digunakan dalam melakukan suatu analisis dapat dilakukan dengan menggunakan analisis rasio, Trend dan Common Size.

Analasis laporan keuangan Koperasi Wanita Kartini Praya dan Koperasi Wanita Kiblat Praya perlu dilakukan untuk memberikan Gambaran mengenai kondisi kinerja keuangan kedua koperasi sehingga dapat digunakan sebagai landasan dalam mengambil keputusan terkait dengan kemajuan Koperasi Wanita Kartini Praya dan Koperasi Wanita Kiblat Praya. Analisis laporan keuangan pada dasarnya dilakukan untuk mengadakan penilaian atas keadaan keuangan Koperasi Wanita Kartini Praya dan Koperasi Wanita Kiblat Praya serta melihat potensi atau kemajuannya melalui laporan keuangan masingmasing koperasi.

Analisis laporan keuangan mencakup pengimplementasian berbagai alat dan teknik analisis pada laporan dan data keuangan dalam rangka untuk memperoleh ukuran dan hubungan yang berarti dan berguna dalam proses pengambilan keputusan. Dengan demikian tujuan analisis laporan keuangan adalah untuk mengkonversikan data menjadi informasi.

Analisis keuangan Koperasi Wanita Kartini Praya dan Koperasi Wanita Kiblat Praya bertujuan untuk menyederhanakan informasi yang menggambarkan hubungan antara pos-pos tertentu dengan pos lainnya yang dilaporkan. Dalam hal ini analisis yang dimaksudkan adalah analisis rasio, trend dan Common Size pada Koperasi Wanita Kartini Praya dan Koperasi Wanita Kiblat Praya yang pada akhirnya akan menggali informasi dari laporan neraca keuangan. Analisis keuangan kegiatannya meliputi pengevaluasian aspek-aspek keuangan. Dengan mengetahui hasil evaluasi, maka Koperasi Wanita Kartini Praya dan Koperasi Wanita Kiblat Praya dapat mengetahui kinerjanya berdasarkan indikator atau penyebab terjadinya masalah yang ada.

Berdasarkan dari data Laporan Keuangan yang diproleh dari Koperasi Wanita Kartini Praya dan Koperasi Wanita Kiblat Praya, belum dapat menunjukkan informasi kinerja keuangan koperasi yang lebih mendalam dan berguna. Laporan keuangan tersebut harus diolah dan dianalisa dengan teknik-teknik tertentu agar menjadi laporan keuangan yang akurat dan dapat menilai keadaan keuangan koperasi apakah sudah baik atau belum. Analisa laporan keuangan ini juga dapat digunakan untuk meramalkan kondisi keuangan koperasi di tahun-tahun berikutnya. Maka dari itu, penulis tertarik untuk melakukan penelitian terkait dengan kinerja keuangan koperasi dalam hal ini penulis mengambil kasus di Koperasi Wanita Kartini Praya dan Koperasi Wanita Kiblat Praya. Penulis menggunakan dua koperasi karena ingin mengetahui perbedaan kinerja dari koperasi yang sama-sama milik non pemerintah namun berbeda laporan keuangan 
nya. dimana dari laporan keuangan kedua koperasi menunjukkan adanya perbedaan dalam trend dari tahun ke tahunnya antara Koperasi Wanita Kartini Praya dan Koperasi Wanita Kiblat Praya.

Menurut Jumingan (2006) mendefinisikan kinerja keuangan merupakan Gambaran kondisi keuangan perusahaan pada suatu periode tertentu menyangkut aspek penghimpun dana maupun penyaluran dana, yang biasanya diukur dengan indicator kecukupan modal, likuiditas, dan profitabilitas. Sedangakan Fahmi (2012:2) kinerja keuangan didefinisikan sebagai gambaran dari pencapaian keberhasilan perusahaan dapat diartikan sebagai hasil yang telah dicapai atas berbagai aktifitas yang telah dilakukan.

Pengertian yang dikemukakan oleh para ahli diatas dapat disimpulkan bahwa kinerja keuangan merupakan pencapaian prestasi perusahaan pada suatu periode yang menggambarkan kondisi kesehatan keuangan perusahaan dengan indicator kecukupan modal, likuiditas, dan profitabilitas.

Laporan keuangan merupakan laporan tertulis yang memberikan informasi kuantitatif tentang posisi keuangan dan perubahan-perubahannya, serta hasil yang dicapai selama periode tertentu. Laporan keuangan dapat dijadikan media yang dapat dipakai untuk meneliti kondisi kesehatan perusahaan, dimana laporan keuangan tersebut terdiri dari neraca, perhitungan rugi laba, ikhtisar laba ditahan dan laporan posisi keuangan.

Menurut Munawir (2004:2) mendefinisikan bahwa laporan keuangan adalah hasil dari proses akuntansi yang dapat digunakan sebagai alat untuk berkomunikasi antara data keuangan atau aktivitas suatu perusahaan dengan pihak-pihak yang berkepentingan dengan data atau aktivitas perusahaan tersebut.

Menurut Sutrisno (2008:9) laporan keuangan didefinisikan sebagai hasil akhir dari proses akuntansi yang meliputi dua laporan utama yakni Neraca dan laporan rugi Laba.

Menurut Myer dalam S. Munawir (2004:5) pengertian laporan keuangan adalah dua daftar yang disusun oleh akuntan pada akhir periode untuk suatu perusahaan. Kedua daftar tersebut adalah daftar neraca atau posisi keuangan dan daftar pendapatan atau daftar laba rugi. Pada waktu akhir-akhir ini sudah menjadi kebiasaan bagi perseroanperseroan untuk menambahkan daftar ketiga yaitu daftar surplus atau daftar laba yang tak dibagikan (laba yang ditahan).

Dari beberapa pendapat ahli ekonomi diatas, maka dapat disimpulkan bahwa pengertian laporan keuangan merupakan hasil akhir proses akuntansi yang menjelaskan atau melaporkan kegiatan perusahaan sekaligus untuk mengevaluasi keberhasilan strategi perusahaan dalam pencapaian tujuan yang ingin dicapai.

Analisis terhadap laporan keuangan dapat digunakan untuk mengukur perkembangan serta kinerja keuangan suatu perusahaan dimasa lalu serta pada masa sekarang yang juga dapat digunakan untuk memperkirakan kondisi keuangan perusahaan sehingga bermanfaat untuk mengetahui kelemahan serta peluang yang ada. Analisis tersebut diantaranya, yaitu:

\section{a. Analisi Trend}

Analisis Trend, (garis trend) atau tendensi merupakan analisis laporan keuangan yang biasanya dinyatakan dalam persentase tertentu. Pengertian dari trend yang dikemukakan oleh Sudarsono dan Edilius (2004:233) mengatakan bahwa untuk menghitung angka-angka trend dapat dilakukan dengan cara menggunakan tahun awal analisis sebagai tahun dasarnya. Untuk menentukan angka trend dari tahun- 
tahun selanjutnya dapat diperoleh dari persentase selisih antara tahun yang diteliti dengan tahun awal sebagai tahun dasarnya, demikian seterusnya.

\section{b. Analisis Common Size}

Analisis Common Size merupakan analisis vertical, dimana analisis ini dilakukan dengan cara merubah angka-angka yang ada dalam neraca dan laporan laba rugi menjadi persentase berdasarkan angka tertentu. Analisis Common Size dilakukan dengan membandingkan per komponen atau per pos dengan total aktiva maupun per komponen terhadap total passivanya (John Wild, 2005:34).

\section{c. Analisis Rasio}

Analisis rasio merupakan suatu metode perhitungan dan interpretasi rasio keuangan untuk menilai kinerja dan kondisi financial suatu perusahaan.Rasio menggambarkan suatu hubungan atau perimbangan antara jumlah yang lain, dan dengan menggunakan alat analisis berupa rasio ini akan menjelaskan dan memberikan gambaran tentang posisi keuangan suatu perusahaan terutama apabila angka rasio tersebut dibandingkan dengan angka rasio pembanding yang digunakan sebagai standar (Munawir, 1996:64).

Penelitian ini menggunakan beberapa analisis untuk mengetahui kinerja keuangan Koperasi Wanita Kartini Praya dan Koperasi Wanita Kiblat Praya diantaranya menggunakan analisis Rasio, Trend dan Common Size.

\section{Metode Penelitian}

Jenis penelitian yang digunakan dalam penelitian ini adalah jenis penelitian komparatif. Penelitian ini menggunakan teknik dokumentasi. Jenis data yang digunakan dalam penelitian ini adalah data kuantitatif yaitu berupa laporan keuangan Koperasi Wanita Kartini Praya dan Koperasi Wanita Kiblat Praya dari tahun 2012-2014. Adapaun mengenai variabel yang adakan diteliti adalah (1) Analisis Trend, (2) Analisis Common Size, (3) Rasio Modal sendiri terhadap total aset, (4) Rasio efisiensiRasio aktiva tetap terhadap total asset, (5) Rasio likuiditas, (6) Rasio rentabilitas aset, (7) Rasio rentabilitas modal sendiridan (8) Rasio kemandirian operasional pelayanan. Metode analsis data yang digunakan adalah, analisis Trendanalisis Common Size dan analisis Rasio sesuai dengan keputusan Menteri Koperasi dan Usaha Kecil dan Menengah No. 35.3/Per/ M.KUKM/ X/ 2007.

\section{Hasil Penelitian dan Pembahasan}

\section{Analisis Rasio}

Hasil perhitungan rasio keuangan Koperasi Wanita Kartini Praya dan Koperasi Wanita Kiblat Praya dari tahun 2010-2014 dapat dilihat pada hasil analisis data setiap rasio keuangan dibawah ini

\section{a. Rasio Modal Sendiri Terhadap Total Aset}

Hasil analsis data mengenai rasio modal sendiri terhadap total aset Koperasi Wanita Kartini Praya dan Koperasi Wanita Kiblat Praya dapat dilihat pada Tabel 1 di bawah ini. 
Tabel 1. Perbandingan Rasio Modal Sendiri Terhadap Total Aset Koperasi Wanita Kartini dan Wanita Kiblat Praya

\begin{tabular}{cccc}
\hline \multicolumn{4}{c}{ Rasio Modal Sendiri Terhadap Total Aset } \\
\hline \multirow{2}{*}{ Tahun } & \multicolumn{3}{c}{ Koperasi Kartini } \\
\cline { 2 - 4 } & Nilai Rasio (\%) & Skor & Kriteria \\
\hline 2010 & 87,32 & 21,83 & Sehat \\
2011 & 86,44 & 21,61 & Sehat \\
2012 & 87,98 & 21,99 & Sehat \\
2013 & 89,47 & 22,37 & Sehat \\
2014 & 90,70 & 22,68 & Sehat \\
Rata-rata & 88,38 & 22,10 & Sehat \\
\hline
\end{tabular}

Koperasi Kiblat

\begin{tabular}{cccc} 
Tahun & Nilai Rasio (\%) & Skor & Kriteria \\
\hline 2010 & 82,68 & 20,67 & Sehat \\
\hline 2011 & 87,73 & 21,93 & Sehat \\
2012 & 88,94 & 22,23 & Sehat \\
2013 & 87,80 & 21,95 & Sehat \\
2014 & 90,44 & 22,61 & Sehat \\
Rata-rata & 87,52 & 21,88 & Sehat \\
\hline
\end{tabular}

Jika ditinjau dari keputusan Menteri Koperasi dan Usaha Kecil dan Menengah No. 35.3/ Per/ M.KUKM/ X/ 2007 mengenai kriteria rasio keuangan maka rasio Modal sendiri terhadap total aset Koperasi Kartini Praya dan Koperasi Wanita Kiblat Praya berada dalam kriteria sehat.

b. Rasio Efisiensi

Hasil analsis data mengenai rasio efiseinsi Koperasi Wanita Kartini Praya dan Koperasi Wanita Kiblat Praya dapat dilihat pada Tabel 2 di bawah ini.

Tabel 2. Perbandingan Rasio Efisiensi Koperasi Wanita Kartini dan wanita Kiblat Praya

\begin{tabular}{|c|c|c|c|}
\hline \multicolumn{4}{|c|}{ Rasio Efisiensi } \\
\hline \multirow[b]{2}{*}{ Tahun } & \multicolumn{3}{|c|}{ Koperasi Kartini } \\
\hline & $\begin{array}{c}\text { Nilai } \\
\text { Rasio (\%) }\end{array}$ & $\begin{array}{l}\text { Sk } \\
\text { or }\end{array}$ & $\begin{array}{c}\text { Krite } \\
\text { ria }\end{array}$ \\
\hline 2010 & 33,27 & 4 & $\begin{array}{c}\text { efisie } \\
n\end{array}$ \\
\hline 2011 & 32,83 & 4 & $\begin{array}{c}\text { efisie } \\
n\end{array}$ \\
\hline 2012 & 30,16 & 4 & $\begin{array}{c}\text { efisie } \\
n\end{array}$ \\
\hline 2013 & 28,73 & 4 & $\begin{array}{c}\text { efisie } \\
n\end{array}$ \\
\hline 2014 & 30,47 & 4 & $\begin{array}{c}\text { efisie } \\
n\end{array}$ \\
\hline $\begin{array}{c}\text { Rata- } \\
\text { rata }\end{array}$ & 31,09 & 4 & $\begin{array}{c}\text { efisie } \\
n\end{array}$ \\
\hline Tahun & \multicolumn{3}{|c|}{ Koperasi Kiblat } \\
\hline
\end{tabular}




\begin{tabular}{cccc} 
& $\begin{array}{c}\text { Nilai } \\
\text { Rasio (\%) }\end{array}$ & $\begin{array}{c}\text { Sk } \\
\text { or }\end{array}$ & $\begin{array}{c}\text { Krite } \\
\text { ria }\end{array}$ \\
\hline 2010 & 37,21 & 4 & $\begin{array}{c}\text { Efisi } \\
\text { en }\end{array}$ \\
2011 & 46,67 & 4 & $\begin{array}{c}\text { Efisi } \\
\text { en }\end{array}$ \\
2012 & 32,17 & 4 & $\begin{array}{c}\text { Efisi } \\
\text { en }\end{array}$ \\
2013 & 39,36 & 4 & $\begin{array}{c}\text { Efisi } \\
\text { en }\end{array}$ \\
2014 & 35,04 & 4 & $\begin{array}{c}\text { Efisi } \\
\text { en } \\
\text { Efisi } \\
\text { en }\end{array}$ \\
$\begin{array}{c}\text { Rata- } \\
\text { rata }\end{array}$ & 38,09 & 4 & \begin{tabular}{c} 
Esala \\
\hline
\end{tabular}
\end{tabular}

Jika ditinjau dari keputusan Menteri Koperasi dan Usaha Kecil dan Menengah No. 35.3/ Per/ M.KUKM/ X/ 2007 mengenai kriteria rasio keuangan maka rasio Efisiensi Koperasi Kartini Praya dan Koperasi Wanita Kiblat Praya berada dalam kriteria Efisien.

\section{c. Rasio Aktiva Tetap Terhadap Total Aset}

Hasil analsis data mengenai rasio rasio aktiva tetap terhadap total aset Koperasi Wanita Kartini Praya dan Koperasi Wanita Kiblat Praya dapat dilihat pada Tabel 3 di bawah ini.

Tabel 3. Perbandingan Rasio Aktiva Tetap Terhadap Total Aset Koperasi Wanita Kartini dan Wanita Kiblat Praya

\begin{tabular}{|c|c|c|c|}
\hline \multicolumn{4}{|c|}{$\begin{array}{c}\text { Rasio Aktiva Tetap Terhadap } \\
\text { Total Aset }\end{array}$} \\
\hline \multirow{3}{*}{ Tahun } & \multicolumn{3}{|c|}{ Koperasi Kartini } \\
\hline & Nilai & Sk & Krite \\
\hline & Rasio (\%) & or & ria \\
\hline 2010 & 0,05 & 4 & Baik \\
\hline 2011 & 0,03 & 4 & Baik \\
\hline 2012 & 0,02 & 4 & Baik \\
\hline 2013 & 0,01 & 4 & Baik \\
\hline 2014 & 0,00 & 4 & Baik \\
\hline $\begin{array}{l}\text { Rata- } \\
\text { rata }\end{array}$ & 0,02 & 4 & Baik \\
\hline \multirow{3}{*}{ Tahun } & \multicolumn{3}{|c|}{ Koperasi Kiblat } \\
\hline & Nilai & $\mathrm{Sk}$ & Krite \\
\hline & Rasio (\%) & or & ria \\
\hline 2010 & 4,52 & 4 & Baik \\
\hline 2011 & 3,87 & 4 & Baik \\
\hline 2012 & 3,35 & 4 & Baik \\
\hline 2013 & 2,83 & 4 & Baik \\
\hline 2014 & 2,57 & 4 & Baik \\
\hline $\begin{array}{l}\text { Rata- } \\
\text { rata }\end{array}$ & 3,43 & 4 & Baik \\
\hline
\end{tabular}


Jika ditinjau dari Keputusan Menteri Koperasi dan Usaha Kecil dan Menengah No. 35.3/ Per/ M.KUKM/ X/ 2007 mengenai kriteria rasio keuangan maka rasio aktiva tetap terhadap total aset Koperasi Kartini Praya dan Koperasi Wanita Kiblat Praya berada dalam kriteria baik.

d. Rasio Likuiditas

Hasil analsis data mengenai rasio likuiditas Koperasi Wanita Kartini Praya dan Koperasi Wanita Kiblat Praya dapat dilihat pada Tabel 4 di bawah ini.

Tabel 4. Perbandingan Rasio Likuiditas Koperasi Wanita Kartini dan Wanita Kiblat Praya

\begin{tabular}{|c|c|c|c|}
\hline \multicolumn{4}{|c|}{ Rasio Likuiditas } \\
\hline \multirow[b]{2}{*}{ Tahun } & \multicolumn{3}{|c|}{ Koperasi Kartini } \\
\hline & $\begin{array}{c}\text { Nilai } \\
\text { Rasio } \\
(\%)\end{array}$ & $\begin{array}{l}\text { Sk } \\
\text { or }\end{array}$ & Kriteria \\
\hline 2010 & 70,15 & 2,5 & $\begin{array}{l}\text { Tidak } \\
\text { Likuid }\end{array}$ \\
\hline 2011 & 115,75 & 2,5 & $\begin{array}{l}\text { Tidak } \\
\text { Likuid }\end{array}$ \\
\hline 2012 & 137,04 & 2,5 & $\begin{array}{l}\text { Tidak } \\
\text { Likuid }\end{array}$ \\
\hline 2013 & 108,37 & 2,5 & $\begin{array}{l}\text { Tidak } \\
\text { Likuid }\end{array}$ \\
\hline 2014 & 176,34 & 2,5 & $\begin{array}{l}\text { Tidak } \\
\text { Likuid }\end{array}$ \\
\hline $\begin{array}{l}\text { Rata- } \\
\text { rata }\end{array}$ & 121,53 & 2,5 & $\begin{array}{l}\text { Tidak } \\
\text { Likuid }\end{array}$ \\
\hline & & eras & iblat \\
\hline Tahun & $\begin{array}{c}\text { Nilai } \\
\text { Rasio } \\
(\%)\end{array}$ & $\begin{array}{l}\text { Sk } \\
\text { or }\end{array}$ & Kriteria \\
\hline 2010 & 187,18 & 2,5 & $\begin{array}{l}\text { Tidak } \\
\text { Likuid }\end{array}$ \\
\hline 2011 & 198,28 & 2,5 & $\begin{array}{l}\text { Tidak } \\
\text { Likuid }\end{array}$ \\
\hline 2012 & 361,51 & 2,5 & $\begin{array}{l}\text { Tidak } \\
\text { Likuid }\end{array}$ \\
\hline 2013 & 253,84 & 2,5 & $\begin{array}{l}\text { Tidak } \\
\text { Likuid }\end{array}$ \\
\hline 2014 & 287,63 & 2,5 & $\begin{array}{l}\text { Tidak } \\
\text { Likuid }\end{array}$ \\
\hline $\begin{array}{c}\text { Rata- } \\
\text { rata }\end{array}$ & 257,69 & 2,5 & $\begin{array}{l}\text { Tidak } \\
\text { Likuid }\end{array}$ \\
\hline
\end{tabular}

Jika ditinjau dari keputusan Menteri Koperasi dan Usaha Kecil dan Menengah No. 35.3/ Per/ M.KUKM/ X/ 2007 mengenai kriteria rasio keuangan maka rasio likuiditas Koperasi Kartini Praya dan Koperasi Wanita Kiblat Praya berada dalam kriteria tidak likuid. 


\section{e. Rasio Rentabilitas Aset}

Hasil analsis data mengenai rasio Rentabilitas Aset Koperasi Wanita Kartini Praya dan Koperasi Wanita Kiblat Praya dapat dilihat pada Tabel 5 di bawah ini.

Tabel 5. Perbandingan Rasio Rentabilitas Aset Koperasi Wanita Kartini dan Wanita Kiblat Praya

\begin{tabular}{|c|c|c|c|}
\hline \multicolumn{4}{|c|}{ Rasio Rentabilitas Aset } \\
\hline \multirow[b]{2}{*}{ Tahun } & \multicolumn{3}{|c|}{ Koperasi Kartini } \\
\hline & $\begin{array}{c}\text { Nilai } \\
\text { Rasio (\%) }\end{array}$ & $\begin{array}{l}\text { Sk } \\
\text { or }\end{array}$ & $\begin{array}{c}\text { Krite } \\
\text { ria }\end{array}$ \\
\hline 2010 & 11,27 & $\begin{array}{c}3,0 \\
0\end{array}$ & $\begin{array}{c}\text { Ting } \\
\text { gi }\end{array}$ \\
\hline 2011 & 10,12 & $\begin{array}{c}3,0 \\
0\end{array}$ & $\begin{array}{l}\text { Ting } \\
\text { gi }\end{array}$ \\
\hline 2012 & 10,93 & $\begin{array}{c}3,0 \\
0\end{array}$ & $\begin{array}{l}\text { Ting } \\
\text { gi }\end{array}$ \\
\hline 2013 & 11,71 & $\begin{array}{c}3,0 \\
0\end{array}$ & $\begin{array}{l}\text { Ting } \\
\text { gi }\end{array}$ \\
\hline 2014 & 11,44 & $\begin{array}{c}3,0 \\
0\end{array}$ & $\begin{array}{l}\text { Ting } \\
\text { gi }\end{array}$ \\
\hline $\begin{array}{l}\text { Rata- } \\
\text { rata }\end{array}$ & 11,10 & $\begin{array}{c}3,0 \\
0\end{array}$ & $\begin{array}{l}\text { Ting } \\
\text { gi }\end{array}$ \\
\hline & Kopera & $\mathrm{i} \mathrm{Kil}$ & \\
\hline Tahun & $\begin{array}{c}\text { Nilai } \\
\text { Rasio (\%) }\end{array}$ & $\begin{array}{l}\text { Sk } \\
\text { or }\end{array}$ & $\begin{array}{c}\text { Krite } \\
\text { ria }\end{array}$ \\
\hline 2010 & 10,95 & $\begin{array}{c}3,0 \\
0\end{array}$ & $\begin{array}{c}\text { Ting } \\
\text { gi }\end{array}$ \\
\hline 2011 & 7,72 & $\begin{array}{c}2,2 \\
5\end{array}$ & $\begin{array}{c}\text { Cuku } \\
\mathrm{p}\end{array}$ \\
\hline 2012 & 10,69 & $\begin{array}{c}3,0 \\
0\end{array}$ & $\begin{array}{l}\text { Ting } \\
\text { gi }\end{array}$ \\
\hline 2013 & 9,41 & $\begin{array}{c}2,2 \\
5\end{array}$ & $\begin{array}{c}\text { Cuku } \\
\mathrm{p}\end{array}$ \\
\hline 2014 & 10,35 & $\begin{array}{c}3,0 \\
0\end{array}$ & $\begin{array}{l}\text { Ting } \\
\text { gi }\end{array}$ \\
\hline $\begin{array}{c}\text { Rata- } \\
\text { rata }\end{array}$ & 9,82 & $\begin{array}{c}2,2 \\
5\end{array}$ & $\begin{array}{c}\text { Cuku } \\
\mathrm{p}\end{array}$ \\
\hline
\end{tabular}

Jika ditinjau dari keputusan Menteri Koperasi dan Usaha Kecil dan Menengah No. 35.3/ Per/ M.KUKM/ X/ 2007 mengenai kriteria rasio keuangan maka rasio Rentabilitas Aset Koperasi Kartini Praya berada dalam kriteria tinggi dan rasio rentabilitas aset Koperasi Wanita Kiblat Praya berada dalam kriteria cukup.

\section{f. Rasio Rentabilitas Modal Sendiri}

Hasil analsis data mengenai rasio rentabilitas modal sendiri Koperasi Wanita Kartini Praya dan Koperasi Wanita Kiblat Praya dapat dilihat pada Tabel 6 di bawah ini. 
Tabel 6 Perbandingan Rasio Rentabilitas modal sendiri Koperasi Wanita Kartini dan Wanita Kiblat Praya

\begin{tabular}{cccc}
\hline \multicolumn{4}{c}{ Rasio Rentabilitas Modal Sendiri } \\
\hline \multirow{2}{*}{ Tahun } & \multicolumn{3}{c}{ Koperasi Kartini } \\
\cline { 2 - 4 } & Nilai Rasio (\%) & Skor & Kriteria \\
\hline 2010 & 12,91 & 3,00 & Tinggi \\
2011 & 11,70 & 3,00 & Tinggi \\
2012 & 12,43 & 3,00 & Tinggi \\
2013 & 13,09 & 3,00 & Tinggi \\
2014 & 12,61 & 3,00 & Tinggi \\
\hline Rata-rata & 12,55 & 3,00 & Tinggi \\
\hline \multirow{2}{*}{ Tahun } & \multicolumn{3}{c}{ Koperasi Kiblat } \\
\cline { 2 - 4 } 2010 & Nilai Rasio (\%) & Skor & Kriteria \\
2011 & 13,24 & 3,00 & Tinggi \\
2012 & 8,80 & 2,25 & Cukup \\
2013 & 12,02 & 3,00 & Tinggi \\
2014 & 10,71 & 3,00 & Tinggi \\
Rata-rata & 11,44 & 3,00 & Tinggi \\
\hline \multicolumn{4}{c}{}
\end{tabular}

Jika ditinjau dari Keputusan Menteri Koperasi dan Usaha Kecil dan Menengah No. 35.3/ Per/ M.KUKM/ X/ 2007 mengenai kriteria rasio keuangan maka rasio rentabilitas modal sendiri Koperasi Kartini Praya dan Koperasi Wanita Kiblat Praya berada dalam kriteria tinggi.

g. Rasio Kemandirian operasional pelayanan

Adapun hasil analsis data mengenai rasio Kemandirian operasional pelayanan Koperasi Wanita Kartini Praya dan Koperasi Wanita Kiblat Praya dapat dilihat pada Tabel 4.21 di bawah ini.

Tabel. 7 Perbandingan Rasio Kemandirian operasional pelayanan Koperasi Wanita Kartini dan Wanita Kiblat Praya

\begin{tabular}{cccc}
\hline \multicolumn{4}{c}{ Rasio Kemandirian Operasional Pelayanan } \\
\hline \multirow{2}{*}{ Tahun } & \multicolumn{3}{c}{ Koperasi Kartini } \\
\cline { 2 - 4 } & Nilai Rasio (\%) & Skor & Kriteria \\
\hline 2010 & 300,59 & 4 & Tinggi \\
2011 & 304,59 & 4 & Tinggi \\
2012 & 331,51 & 4 & Tinggi \\
2013 & 348,10 & 4 & Tinggi \\
2014 & 328,24 & 4 & Tinggi \\
Rata-rata & 322,61 & 4 & Tinggi \\
\hline \multirow{4}{*}{ Tahun } & \multicolumn{4}{c}{ Koperasi Kiblat } \\
\cline { 2 - 4 } 2010 & 268,74 & 4 & Tinggi \\
2011 & 214,26 & 4 & Tinggi \\
2012 & 310,89 & 4 & Tinggi \\
2013 & 254,04 & 4 & Tinggi \\
2014 & 285,36 & 4 & Tinggi \\
Rata-rata & 266,66 & 4 & Tinggi \\
\hline
\end{tabular}


Jika ditinjau dari keputusan Menteri Koperasi dan Usaha Kecil dan Menengah No. 35.3/ Per/ M.KUKM/ X/ 2007 mengenai kriteria rasio keuangan maka rasio kemandirian operasional pelayanan Koperasi Kartini Praya dan Koperasi Wanita Kiblat Praya berada dalam kriteria tinggi.

\section{Analisis Trend}

Analisis Trend yaitu analisis yang digunakan untuk melihat perubahan atau naik turunnya nilai rasio keuangan koperasi dalam beberapa tahun sehingga dapat diketahui perkembangan usahanya.

a. Trend Rasio Modal Sendiri terhadap Total Modal

Dari hasil analisis Trend di ketahui bahwa Trend rasio modal sendiri terhadap total aset untuk Koperasi Wanita Kartini Praya cenderung mengalami peningkatan, sedangakan Trend rasio modal sendiri terhadap total modal untuk Koperasi Wanita Kiblat Praya cenderung juga mengalami peningkatan.

\section{b. Trend Rasio Efisiensi}

Dari hasil analisis Trenddiketahui bahwa trend rasio efisiensi untuk Koperasi Wanita Kartini Praya cenderung mengalami penurunan, sedangakan trend rasio efisiensi untuk Koperasi Wanita Kiblat Praya cenderung mengalami peningkatan penurunan dan peningkatan.

c. Trend Rasio Aktiva Tetap terhadap Total Aset

Dari hasil analisis Trenddiketahui bahwa trend rasio aktiva tetap terhadap total aset untuk Koperasi Wanita Kartini Praya cenderung mengalami penurunan, sedangakan trend rasio aktiva tetap terhadap total aset untuk Koperasi Wanita Kiblat Praya cenderung juga mengalami penurunan.

\section{d. Trend Rasio Likuiditas}

Dari hasil analisis Trenddiketahui bahwa trend rasio likuiditas untuk Koperasi Wanita Kartini Praya cenderung mengalami peningkatan, sedangakan trend rasio likuiditas untuk Koperasi Wanita Kiblat Praya cenderung juga mengalami peningkatan.

e. Trend Rasio Rentabilitas Aset

Dari hasil analisis Trenddiketahui bahwa trend rasio rentabilitas aset untuk Koperasi Wanita Kartini Praya cenderung mengalami peningkatan dan penurunan, sedangakan trend rasio rentabilitas aset untuk Koperasi Wanita Kiblat Praya cenderung juga mengalami peningkatan dan penurunan.

\section{f. Trend Rasio Rentabilitas Modal Sendiri}

Dari hasil analisis Trenddiketahui bahwa trend rasio rentabilitas modal sendiri untuk Koperasi Wanita Kartini Praya cenderung mengalami peningkatan dan penurunan, sedangakan trend rasio rentabilitas modal sendiri untuk Koperasi Wanita Kiblat Praya cenderung juga mengalami peningkatan dan penurunan.

\section{g. Trend Rasio Kemandirian Operasional}

Dari hasil analisis Trenddiketahui bahwa trend rasio kemandirian operasional pelayanan untuk Koperasi Wanita Kartini Praya cenderung mengalami peningkatan, sedangakan trend rasio kemandirian operasional pelayanan untuk Koperasi Wanita Kiblat Praya cenderung mengalami peningkatan dan penurunan

\section{Analisis Common Size}

Analsis Common Size dilakukan dengan cara merubah angka-angka yang ada dalam neraca dan laporan laba rugi menjadi persentase berdasarkan angka tertentu yang dinyatakan dalam persen (\%). Hasil perbandingan Common Size Koperasi Wanita Kartini Praya dan Koperasi Wanita Kiblat Praya akan dibahas sebagai berikut. 


\section{a. Aktiva Lancar}

Adapun perbandingan hasil analisis Common Size aktiva lancar Koperasi Wanita Kartini Praya dan Koperasi Wanita Kiblat Praya dapat dilihat pada Tabel. 8 dibawah ini.

Tabel. 8 Perbandingan Common Size Aktiva Lancar Koperasi Wanita Kartini dan Wanita Kiblat Praya

\begin{tabular}{ccc}
\hline & \multicolumn{2}{c}{ Aktiva Lancar } \\
\cline { 2 - 3 } Tahun & $\begin{array}{c}\text { Koperasi } \\
\text { Kartini } \\
(\%)\end{array}$ & $\begin{array}{c}\text { Kopera } \\
\text { si } \\
\text { Kiblat } \\
(\%)\end{array}$ \\
\hline 2010 & 99.95 & 95.48 \\
2011 & 99.97 & 96.13 \\
2012 & 99.98 & 96.65 \\
2013 & 99.99 & 97.17 \\
\hline 2014 & 100 & 97.43 \\
Rata-rata & 99.98 & 96.58 \\
\hline
\end{tabular}

Koperasi Wanita Kartini Praya memiliki rata-rata nilai aktiva lancar sebesar 99,98\% dari total aktivanya, sedangkan Koperasi Wanita Kiblat Praya memiliki rata-rata nilai aktiva lancar sebesar $96,57 \%$ dari total aktivanya.

b. Aktiva tetap

Adapun perbandingan hasil analisis Common Size aktiva tetap Koperasi Wanita Kartini Praya dan Koperasi Wanita Kiblat Praya dapat dilihat pada Tabel.9 dibawah ini.

Tabel.9 Perbandingan Common Size Aktiva Tetap Koperasi Wanita Kartini dan Wanita Kiblat Praya

\begin{tabular}{ccc}
\hline & \multicolumn{2}{c}{ Aktiva Tetap } \\
\cline { 2 - 3 } Tahun & $\begin{array}{c}\text { Koperasi } \\
\text { Kartini } \\
(\%)\end{array}$ & $\begin{array}{c}\text { Kopera } \\
\text { si } \\
\text { Kiblat } \\
(\%)\end{array}$ \\
\hline 2010 & 0.05 & 4.52 \\
2011 & 0.03 & 3.87 \\
2012 & 0.02 & 3.35 \\
2013 & 0.01 & 2.83 \\
2014 & 0 & 2.57 \\
$\begin{array}{c}\text { Rata- } \\
\text { rata }\end{array}$ & 0.02 & 3.43 \\
\hline
\end{tabular}

Koperasi Wanita Kartini Praya memiliki rata-rata nilai aktiva tetap sebesar 0,02\% dari total aktivanya, sedangkan Koperasi Wanita Kiblat Praya memiliki rata-rata nilai aktiva tetap sebesar 3,43\% dari total aktivanya.

c. Kewajiban lancar

Adapun perbandingan hasil analisis Common Size kewajiban lancar Koperasi Wanita Kartini Praya dan Koperasi Wanita Kiblat Praya dapat dilihat pada Tabel. 10 dibawah ini. 
Tabel. 10 Perbandingan Common Size Kewajiban Lancar Koperasi Wanita Kartini dan Wanita Kiblat Praya

\begin{tabular}{ccc}
\hline \multirow{2}{*}{ Tahun } & \multicolumn{2}{c}{ Kewajiban lancar } \\
\cline { 2 - 3 } & $\begin{array}{c}\text { Koperasi } \\
\text { kartini } \\
(\%)\end{array}$ & $\begin{array}{c}\text { Kopera } \\
\text { si kiblat } \\
(\%)\end{array}$ \\
\hline 2010 & 12.68 & 17.32 \\
2011 & 13.56 & 12.27 \\
2012 & 12.02 & 11.06 \\
2013 & 10.53 & 12.2 \\
2014 & 9.3 & 9.56 \\
Rata-rata & 11.62 & 12.49
\end{tabular}

Koperasi Wanita Kartini Praya memiliki rata-rata nilai kewajiban lancar sebesar $11,62 \%$ dari total pasivanya, sedangkan Koperasi Wanita Kiblat Praya memiliki ratarata nilai kewajiban lancar sebesar $12,49 \%$ dari total pasivaya.

\section{d. Kekayaan Bersih}

Adapun perbandingan hasil analisis Common Size Koperasi Wanita Kartini Praya dan Koperasi Wanita Kiblat Praya dapat dilihat pada Tabel. 10 dibawah ini.

Tabel. 11 Perbandingan Common Size Kekayaan Bersih Koperasi Wanita Kartini dan Wanita Kiblat Praya

\begin{tabular}{ccc}
\hline \multirow{2}{*}{ Tahun } & \multicolumn{2}{c}{ Kekayaan Bersih } \\
\cline { 2 - 3 } & $\begin{array}{c}\text { Koperasi } \\
\text { Kartini } \\
(\%)\end{array}$ & $\begin{array}{c}\text { Koperasi } \\
\text { Kiblat } \\
(\%)\end{array}$ \\
\hline 2010 & 87.32 & 82.68 \\
2011 & 86.44 & 87.73 \\
2012 & 87.98 & 88.94 \\
2013 & 89.47 & 87.8 \\
2014 & 90.7 & 90.44 \\
$\begin{array}{c}\text { Rata- } \\
\text { rata }\end{array}$ & 88.38 & 87.52 \\
\hline
\end{tabular}

Koperasi Wanita Kartini Praya memiliki rata-rata nilai kekayaan bersih sebesar $88,38 \%$ dari total pasivanya, sedangkan Koperasi Wanita Kiblat Praya memiliki ratarata nilai kekayaan bersih sebesar $87,52 \%$ dari total pasivanya.

\section{e. Pendapatan jasa}

Adapun perbandingan hasil analisis Common Size pendapatan jasa simpan pinjam Koperasi Wanita Kartini Praya dan Koperasi Wanita Kiblat Praya dapat dilihat pada Tabel. 11 dibawah ini. 
Tabel. 12 Perbandingan Common Size Pendapatan Jasa Koperasi Wanita Kartini dan Wanita Kiblat Praya

\begin{tabular}{ccc}
\hline & \multicolumn{2}{c}{ Pendaptan Jasa } \\
\cline { 2 - 3 } Tahun & $\begin{array}{c}\text { Koperasi } \\
\text { Kartini } \\
(\%)\end{array}$ & $\begin{array}{c}\text { Koperasi } \\
\text { Kiblat } \\
(\%)\end{array}$ \\
\hline 2010 & 93.44 & 99.38 \\
2011 & 93.37 & 99.24 \\
2012 & 92.43 & 100 \\
2013 & 91.67 & 100 \\
2014 & 93.5 & 99.9 \\
$\begin{array}{c}\text { Rata- } \\
\text { rata }\end{array}$ & 92.88 & 99.7 \\
\hline
\end{tabular}

Koperasi Wanita Kartini Praya memiliki rata-rata nilai pendapatan sebesar 92,88\% dari total pendapatannya, sedangkan Koperasi Wanita Kiblat Praya memiliki ratarata nilai pendapatan sebesar $99,70 \%$ dari total pendapatannya.

\section{f. Pendapatan Lain-Lain}

Adapun perbandingan hasil analisis Common Size pendapatan lain-lain Koperasi Wanita Kartini Praya dan Koperasi WanitaKiblat Praya dapat dilihat pada Tabel.12 dibawah ini.

Tabel 13. Perbandingan Common Size Pendapatan Lain-Lain Koperasi Wanita Kartini dan Wanita Kiblat Praya

\begin{tabular}{ccc}
\hline & \multicolumn{2}{c}{$\begin{array}{c}\text { Pendapatan Lain- } \\
\text { lain }\end{array}$} \\
\cline { 2 - 3 } Tahun & $\begin{array}{c}\text { Koperasi } \\
\text { Kartini } \\
(\%)\end{array}$ & $\begin{array}{c}\text { Koperasi } \\
\text { Kiblat } \\
(\%)\end{array}$ \\
\hline 2010 & 6.56 & 0.62 \\
2011 & 6.63 & 0.77 \\
2012 & 7.57 & 0 \\
2013 & 8.33 & 0 \\
2014 & 6.5 & 0.1 \\
Rata- \\
rata
\end{tabular}

Koperasi Wanita Kartini Praya memiliki rata-rata nilai pendaptan lain-lain sebesar 7,12\% dari total pendapatannya, sedangkan Koperasi Wanita Kiblat Praya memiliki rata-rata nilai pendapatan lain-lain sebesar $0,30 \%$ dari total pendapatannya.

g. Biaya-biaya

Adapun perbandingan hasil analisis Common Size biaya-biaya Koperasi Wanita Kartini Praya dan Koperasi Wanita Kiblat Praya dapat dilihat pada Tabel 13 dibawah ini. 
Tabel 13. Perbandingan Common Size Biaya-Biaya Koperasi Wanita Kartini dan Wanita Kiblat Praya

\begin{tabular}{ccc}
\hline & \multicolumn{2}{c}{ Biaya-biaya } \\
\cline { 2 - 3 } Tahun & $\begin{array}{c}\text { Koperasi } \\
\text { Kartini } \\
(\%)\end{array}$ & $\begin{array}{c}\text { Kopera } \\
\text { si } \\
\text { Kiblat } \\
(\%)\end{array}$ \\
\hline 2010 & 33.27 & 37.21 \\
2011 & 32.83 & 46.67 \\
2012 & 30.16 & 32.17 \\
2013 & 28.73 & 39.36 \\
2014 & 30.47 & 35.04 \\
$\begin{array}{c}\text { Rata- } \\
\text { rata }\end{array}$ & 31.09 & 38.09 \\
\hline
\end{tabular}

Koperasi Wanita Kartini Praya memiliki rata-rata nilai biaya-biaya sebesar 31,09\% dari total pendaptannya, sedangkan Koperasi Wanita Kiblat Praya memiliki rata-rata nilai biaya-biaya sebesar 38,09\% dari total pendapatannya.

\section{h. Sisa Hasil Usaha}

Adapun perbandingan hasil analisis Common Size sisa hasil usaha Koperasi Wanita Kartini Praya dan Koperasi Wanita Kiblat Praya dapat dilihat pada Tabel 14 dibawah ini.

Tabel 15. Perbandingan Common Size Sisa Hasil Usaha Koperasi Wanita Kartini dan Wanita Kiblat Praya

\begin{tabular}{ccc}
\hline & \multicolumn{2}{c}{ Sisa Hasil Usaha } \\
\cline { 2 - 3 } Tahun & $\begin{array}{c}\text { Koperas } \\
\text { i Kartini } \\
(\%)\end{array}$ & $\begin{array}{c}\text { Koperasi } \\
\text { Kiblat }(\%)\end{array}$ \\
\hline 2010 & 66.73 & 62.79 \\
2011 & 67.17 & 53.33 \\
2012 & 69.84 & 67.83 \\
2013 & 71.27 & 56.89 \\
2014 & 69.53 & 63.96 \\
$\begin{array}{c}\text { Rata- } \\
\text { rata }\end{array}$ & 68.91 & 60.96 \\
\hline
\end{tabular}

Koperasi Wanita Kartini Praya memiliki rata-rata nilai sisa hasil usaha sebesar 68,91\% dari total pendaptannya, sedangkan Koperasi Wanita Kiblat Praya memiliki rata-rata nilai sisa hasi usah sebesar $60,96 \%$ dari total pendapatannya.

\section{PEMBAHASAN}

Setelah melakukan analisis data pada setiap aspek kinerja keuangan melalui analisis Rasio, Trend dan Common Size diketahuibahwa setiap koperasi memiliki tingkat kinerja berdasarkan masing-masing analisis.

1. Analisis Rasio

Pembahasan mengenai analisis rasio didasarkan pada perbandingan kedua koperasi yang telah dilakukan dalam analisis data. 


\section{a. Rasio Modal Sendiri Terhadap Total Aset}

Koperasi Wanita Kartini Praya dan Koperasi Wanita Kiblat Praya memiliki nilai rasio modal sendiri terhadap total aset diatas $20 \%$ setiap tahun penelitian. Koperasi Wanita Kartini Praya memiliki rata-rata nilai rasio modal sendiri terhadap total aset sebesar 88,38\% sedangkan Koperasi Wanita Kiblat Praya memiliki rata-rata nilai rasio modal sendiri terhadap total aset sebesar $87,52 \%$. Walaupun terdapat selisih rata-rata yaitu sebesar $0,86 \%$ tetapi rasio kedua koperasi tersebut berada pada kriteria sehat. Hal ini berarti bahwa Koperasi Wanita Kartini Praya dan Koperasi Wanita Kiblat Praya memiliki kemampuan yang sama baik dalam menghimpun modal sendiri jika dibandingkan dengan total modal yang dimiliki.

\section{b. Rasio Efisiensi}

Koperasi Wanita Kartini Praya dan Koperasi Wanita Kiblat Praya memiliki nilai rasio efisiensi berada pada rentang $0 \%-68 \%$ setiap tahun penelitian. Koperasi Wanita Kartini Praya memiliki rata-rata nilai rasio efisiensi sebesar 31,09\% sedangkan Koperasi Wanita Kiblat Praya memiliki rata-rata nilai rasio efisiensi sebesar 38,09\%. Walaupun terdapat selisih rata-rata yaitu sebesar 7\% tetapi rasio kedua koperasi tersebut berada pada kriteria efisien. Hal ini berarti bahwa Koperasi Wanita Kartini Praya dan Koperasi Wanita Kiblat Praya memiliki efisiensi yang sama dalam memberikan pelayanan kepada anggotanya dari penggunaan aset yang dimiliki.

\section{c. Rasio Aktiva Tetap Terhadap Total Aset}

Koperasi Wanita Kartini Praya dan Koperasi Wanita Kiblat Praya memiliki nilai rasio aktiva tetap terhadap total aset berada pada rentang $0 \%-25 \%$ setiap tahun penelitian. Koperasi Wanita Kartini Praya memiliki rata-rata nilai rasio aktiva tetap terhadap total aset sebesar 0,02\% sedangkan Koperasi Wanita Kiblat Praya memiliki rata-rata nilai rasio aktiva tetap terhadap total aset sebesar 3,43\%. Walaupun terdapat selisih rata-rata yaitu sebesar 3,41\% tetapi rasio kedua koperasi tersebut berada pada kriteria baik. Hal ini berarti bahwa Koperasi Wanita Kartini Praya dan Koperasi Wanita Kiblat Praya memiliki kemampuan yang sama baik dalam meningkatkan aktiva dari total aset yang dimiliki.

\section{d. Rasio Likuiditas}

Koperasi Wanita Kartini Praya dan Koperasi Wanita Kiblat Praya memiliki nilai rasio likuiditas berada di atas 56\% setiap tahun penelitian. Koperasi Wanita Kartini Praya memiliki rata-rata nilai rasio likuiditas sebesar 121,53\% sedangkan Koperasi Wanita Kiblat Praya memiliki rata-rata nilai rasio likuiditas sebesar 256,69\%. Kedua koperasi tersebut berada pada kriteria tidak likuid. Hal ini berarti bahwa Koperasi Wanita Kartini Praya dan Koperasi Wanita Kiblat Praya memiliki kemampuan yang rendah dalam dalam memenuhi hutang jangka pendeknya atau kewajiban lancarnya.

\section{e. Rasio Rentabilitas Aset}

Koperasi Wanita Kartini Praya memiliki nilai rasio rentabilitas aset memiliki nilai risio rentabilitas aset di atas $10 \%$ setiap tahun penelitian dengan rata-rata $11,10 \%$ dan berada pada kriteria tinggi sedangkan Koperasi Wanita Kiblat Praya memiliki ratarata nilai rasio likuiditas sebesar 9,82\% dengan kriteria cukup. Hal ini disebabkan karena adannya penurunan nilai rasio yaitu pada tahun 2011 dan 2013, dimana pada kedua tahun tersebut nilai rasio berada pada rentang di bawah $10 \%$. Kondisi kedua koperasi tersebut memberikan kesimpulan bahwa Koperasi Wanita Kartini Praya memiliki kemampuan yang lebiih baik dari Koperasi Wanita Kiblat Praya dalam menghasilkan laba terhadap total asetnya. 


\section{f. Rasio Rentabilitas Modal Sendiri}

Koperasi Wanita Kartini Praya dan Koperasi Wanita Kiblat Praya memiliki nilai rasio rentabilitas modal sendiri berada pada rentang diatas $10 \%$ setiap tahun penelitian. Koperasi Wanita Kartini Praya memiliki rata-rata nilai rasio rentabilitas modal sendiri sebesar 12,55\% sedangkan Koperasi Wanita Kiblat Praya memiliki rata-rata nilai rasio rentabilitas modal sendiri sebesar $11,24 \%$. Walaupun terdapat selisih rata-rata yaitu sebesar $1,31 \%$ tetapi rasio kedua koperasi tersebut berada pada kriteria tinggi. Hal ini berarti bahwa Koperasi Wanita Kartini Praya dan Koperasi Wanita Kiblat Praya memiliki kemampuan yang sama baik dalam menghasilkan laba terhadap total modal sendiri yang dimiliki.

\section{g. Rasio Kemandirian Operasional Pelayanan}

Koperasi Wanita Kartini Praya dan Koperasi Wanita Kiblat Praya memiliki nilai rasio kemandirian operasional pelayanan berada pada rentang diatas $150 \%$ setiap tahun penelitian. Koperasi Wanita Kartini Praya memiliki rata-rata nilai rasio kemandirian operasional pelayanan sebesar 322,61\% sedangkan Koperasi Wanita Kiblat Praya memiliki rata-rata nilai rasio kemandirian operasional pelayanan sebesar $266,66 \%$. Walaupun terdapat selisih rata-rata yaitu sebesar 55,95\% tetapi rasio kedua koperasi tersebut berada pada kriteria tinggi. Hal ini berarti bahwa Koperasi Wanita Kartini Praya dan Koperasi Wanita Kiblat Praya memiliki kemampuan yang sama baik dalam mengelola kegiatan usahanya.

\section{Analisis Trend}

\section{a. Trend rasio Rasio Modal Sendiri Terhadap Total Aset}

Dari hasil analisis data mengenai trend rasio modal sendiri terhadap total aset bahwa Koperasi Wanita Kartini Praya cenderung mengalami peningkatan dari tahun 20102014. Kecenderungan peningkatan tersebut memberikan suatu pengertian bahwa Koperasi Wanita Kartini Praya memiliki kemampuan yang semakin baik dari tahun ke tahun penelitian dalam menghimpun modal sendiri. Hal yang sama terjadi juga dengan trend rasio modal sendiri terhadap total aset Koperasi Wanita Kiblat Praya. Trend rasio modal sendiri terhadap total modal Koperasi Wanita Kiblat Praya cenderung mengalami peningkatan dari tahu 2010-2014. Jika ditinjau dari trend rasio modal sendiri terhadap total aset dapat dikatakan bahwa Koperasi Wanita Kartini Praya dan Koperasi Wanita Kiblat Praya memiliki kemampuan yang sama baiknya dalam menghimpun modal sendiri.

\section{b. Trend efisiensi}

Dari hasil analisis data mengenai trend efisensikoperasi wanita kartin Praya cenderung mengalami penurunan dari tahun 2010-2014. Kecenderungan penurunan tersebut memberikan suatu pengertian bahwa Koperasi Wanita Kartini Praya memiliki kemampuan yang semakin baik dalam memberikan pelayanan yang efisien kepada anggotanya. Berbeda dengan trend efisiensi yang dimiliki oleh Koperasi Wanita Kiblat Praya. Trend efisensi yang dimiliki oleh Koperasi Wanita Kiblat Praya cenderung mengalami peningkatan dan penurunan atau mengalami pluktuas sehingga dapat dikatakan bahwa Koperasi Wanita Kiblat Praya memiliki kemampuan yang masih kurang baik dalam memberikan pelayanan yang efisien kepada anggotanya. Jika ditinjau dari trend efisiensi dapat dikatakan bahwa Koperasi Wanita Kartini Praya lebih baik dalam memberikan pelayanan yang efisien kepada anggotanya.

\section{c. Trend Rasio Aktiva Tetap terhadap Total Aset}

Dari hasil analisis data mengenai trend rasio aktiva tetap terhadap total aset bahwa

Koperasi Wanita Kartini selalu mengalami penurunan dari tahun 2010-2014. 
Kecenderungan penurunan tersebut memberikan suatu pengertian bahwa Koperasi Wanita Kartini Praya semakin efektif dari tahun ke tahun dalam menggunakan aset tetapnya. Hal yang sama terjadi juga dengan trend rasio aktiva tetap terhadap total aset Koperasi Wanita Kiblat Praya. Trend rasio aktiva tetap terhadap total aset Koperasi Wanita Kiblat Praya selalu mengalami penurunan dari tahun 2010-2014. Jika ditinjau dari trend rasio aktiva tetap terhadap total aset dapat dikatakan bahwa Koperasi Wanita Kartini Praya dan Koperasi Wanita Kiblat Praya memiliki kemampuan yang sama baik (efeketif) dalam menggunakan aset tetapnya.

\section{d. Trend Rasio Likuiditas}

Dari hasil analisis data mengenai trend rasio rasio likuiditas bahwa Koperasi Wanita Kartini cenderung mengalami peningkatan dari tahun 2010-2014. Akan tetapi nilai rasio likuiditas berada pada rentang di atas 56\% dengan kriteria tidak likuid. Kecenderungan peningkatan rasio likuiditas dari tahun 2010-2014 memberikan makna bahwa Koperasi Wanita Kartini Praya semakin tidak mampu dalam memenuhi hutang jangka pendeknya. Hal yang sama terjadi juga dengan rasio likuiditas Koperasi Wanita Kiblat Praya. Trend rasio likuiditas Koperasi Wanita Kiblat Praya cenderung mengalami peningktan dari tahun 2010-2014. Jika ditinjau dari rasio likuiditas dapat dikatakan bahwa Koperasi Wanita Kartini Praya dan Koperasi Wanita Kiblat Praya memiliki kemampuan yang kurang dalam memenuhi hutang jangka pendeknya.

\section{e. Trend Rasio Rentabilitas Aset}

Dari hasil analisis data mengenai Trend rasio rentabilitas aset bahwa Koperasi Wanita Kartini Praya cenderung mengalami peningkatan dan penurunan. Kecenderungan tersebut memberikan suatu pengertian bahwa Koperasi Wanita Kartini Praya belum mampu secara baik dan konsisten dalam mengahasilkan laba berdasarkan total aset yang dimilikinya. Hal yang sama terjadi juga dengan trend rasio rentabilitas aset Koperasi Wanita Kiblat Praya. Trend rasio rentabilitas aset Koperasi Wanita Kiblat Praya cenderung mengalami peningkatan dan penurunan dari tahun 2010-2014. Jika ditinjau dari trend rasio rentabilitas aset dapat dikatakan bahwa Koperasi Wanita Kartini Praya dan Koperasi Wanita Kiblat Praya belum mampu secara baik dan konsisten dalam mengahasilkan laba berdasarkan total aset yang dimilikinya.

\section{f. Trend Rasio Rentabilitas Modal Sendiri}

Dari hasil analisis data mengenai trend rasio rentabilitas modal sendiri bahwa Koperasi Wanita Kartini Praya cenderung mengalami peningkatan dan penurunan. Kecenderungan tersebut memberikan suatu pengertian bahwa Koperasi Wanita Kartini Praya belum mampu secara baik dan konsisten dalam mengahasilkan laba berdasarkan total aset yang dimilikinya. Hal yang sama terjadi juga dengan trend rasio rentabilitas modal sendiri Koperasi Wanita Kiblat Praya. Trend rasio rentabilitas modal sendiri Koperasi Wanita Kiblat Praya cenderung mengalami peningkatan dan penurunan dari tahun 2010-2014. Jika ditinjau dari trend rasio rentabilitas modal sendiri dapat dikatakan bahwa Koperasi Wanita Kartini Praya dan Koperasi Wanita Kiblat Praya belum secara baik dalam menghasilkan laba berdasarkan modal sendiri yang dimilikinya.

\section{g. Trend Kemandirian Operasional Pelayanan}

Dari hasil analisis data mengenai trend kemandirian operasional pelayanan Koperasi Wanita Kartini Praya cenderung mengalami peningkatan dari tahun 2010-2014. Kecenderungan peningkatan tersebut memberikan suatu pengertian bahwa Koperasi 
Wanita Kartini Praya memiliki kemampuan yang semakin baik dalam mengelola pendapatan usahanya untuk biaya operasional pelayanan. Berbeda dengan trend kemandirian operasional pelayanan yang dimiliki oleh Koperasi Wanita Kiblat Praya. Trend kemandirian operasional pelayanan yang dimiliki oleh Koperasi Wanita Kiblat Praya cenderung mengalami peningkatan dan penurunan atau mengalami pluktuasi sehingga dapat dikatakan bahwa kemampuan Koperasi Wanita Kartini Praya dalam mengelola pendapatan usahanya untuk biaya operasional pelayanan belum dilakuakan secara baik dan konsisten. Jika ditinjau dari trend kemandirian operasional pelayanan dapat dikatakan bahwa Koperasi Wanita Kartini Praya lebih baik dalam mengelola pendapatan usahanya untuk biaya operasional pelayanan.

\section{Analisis Common Size}

Perbandingan analisis Common Size antara Koperasi Wanita Kartini Praya dengan Koperasi Wanita Kiblat Prayadilihat berdasarkan pos neraca keuangan dan pos laba rugi. Dari masing-masing pos dibandingkan komponen masing-masing pos yang memiliki kontribusi tertinggi dalam pengaruhnya meningkatkan nilai masing-masing pos dalam hal ini yaitu neraca keuangan dan laporan laba rugi.

\section{a. Common Size Neraca Keuangan}

Sebagaiamana diketahui bahwa pos yang ada dalam neraca keuangan diantaranya adalah pos aktiva lancar, aktiva tetap, kewajiban lancar dan kekayaan bersih.

\section{1) Pos Aktiva Lancar}

Koperasi Wanita Kartini Praya memiliki nilai rata-rata total aktiva lancar sebesar 99,98\% dari total aktivanya, sedangkan Koperasi Wanita Kiblat Praya memiliki nilai rata-rata total aktiva lancar sebesar $96,57 \%$. Hal tersebut berarti bahwa setiap Rp 100,- total aktiva yang dimiliki Koperasi Wanita Kartini Praya diinvestasikan pada aktiva lancar sebesar $\mathrm{Rp}$ 99,98,- dan setiap Rp 100,- total aktiva yang dimiliki Koperasi Wanita Kiblat Praya diinvestasikan pada aktiva lancar sebesar Rp 96,57,-. Jika dilihat dari rata-rata total aktiva lancar maka dapat disimpulkan bahwa Koperasi Wanita Kartini Praya memiliki investasi yang lebih besar dibandingakan dengan Koperasi Wanita Kiblat Praya dalam bentuk aktiva lancar.

\section{2) Pos aktiva Tetap}

Koperasi Wanita Kartini Praya memiliki nilai rata-rata total aktiva tetap sebesar $0,02 \%$ dari total aktivanya, sedangkan Koperasi Wanita Kiblat Praya memiliki nilai rata-rata total aktiva tetap sebesar 3,43\%. Hal tersebut berarti bahwa setiap Rp 100,total aktiva yang dimiliki Koperasi Wanita Kartini Praya diinvestasikan pada aktiva tetap sebesar Rp 0,02,- dan setiap Rp 100,- total aktiva yang dimiliki Koperasi Wanita Kiblat Praya diinvestasikan pada aktiva tetap sebesar Rp 3,43,-. Jika dilihat dari rata-rata total aktiva tetap maka dapat disimpulkan bahwa Koperasi Wanita Kiblat Praya memiliki investasi yang lebih besar dibandingakan dengan Koperasi Wanita Kartini Praya dalam bentuk aktiva tetap.

\section{3) Pos kewajiban Lancar}

Koperasi Wanita Kartini Praya memiliki nilai rata-rata total kewajiban lancar sebesar $11,62 \%$ dari total pasivanya, sedangkan Koperasi Wanita Kiblat Praya memiliki nilai rata-rata total kewajiban lancar sebesar $12,48 \%$. Hal tersebut berarti bahwa setiap Rp 100,- total pasiva yang dimiliki Koperasi Wanita Kartini Praya dibiayai dari kewajiban lancar sebesar Rp 11,62,- dan setiap Rp 100,- total pasiva yang dimiliki Koperasi Wanita Kiblat Praya dibiayai dari kewajiban lancar sebesar Rp 12,48,-. Jika dilihat dari rata-rata total kewajiban lancar maka dapat disimpulkan bahwa Koperasi 
Wanita Kiblat Praya memiliki pembiayaan pasiva dari kewajiban lancar yang lebih besar dibandingakan dengan Koperasi Wanita Kartini Praya.

\section{4) Pos Kekayaan Bersih}

Koperasi Wanita Kartini Praya memiliki nilai rata-rata total kekayaan bersih sebesar 88,38\% dari total pasivanya, sedangkan Koperasi Wanita Kiblat Praya memiliki nilai rata-rata total kekayaan bersih sebesar $87,52 \%$. Hal tersebut berarti bahwa setiap Rp 100,- total pasiva yang dimiliki Koperasi Wanita Kartini Praya dibiayai dari kekayaan bersih sebesar Rp. 88,38,- dan setiap Rp 100,- total pasiva yang dimiliki Koperasi Wanita Kiblat Praya dibiayai dari kekayaan bersih sebesar Rp. 87,52,-. Jika dilihat dari rata-rata total kewajiban lancar maka dapat disimpulkan bahwa Koperasi Wanita Kartini Praya memiliki pembiayaan pasiva dari kekayaan bersih yang lebih besar dibandingakan dengan Koperasi Wanita Kiblat Praya.

b. Common Size Laporan Laba Rugi

1) Pendapatan

Koperasi Wanita Kartini Praya memiliki nilai rata-rata pendapatan sebesar Rp. 101.515.321,1sedangkan Koperasi Wanita Kiblat Praya memiliki nilai rata-rata pendapatan sebesar Rp. 134.565.818,2. Jika dilihat dari rata-rata total pendapatan maka dapat disimpulkan bahwa Koperasi Wanita Kiblat Praya memiliki pendapatan lebih besar dibandingakan dengan Koperasi Wanita Kartini Praya.

2) Biaya Operasional

Koperasi Wanita Kartini Praya memiliki nilai rata-rata total biaya-biaya sebesar 31,09\% dari total pendapatannya, sedangkan Koperasi Wanita Kiblat Praya memiliki nilai rata-rata total kekayaan bersih sebesar 38,09\%. Hal ini berarti bahwa setiap Rp 100,- dari total pendapatan Koperasi Wanita Kartini Praya, maka sebesar Rp 31,09,akan terserap dalam biaya operasional koperasi,- dan setiap $\mathrm{Rp} 100$,- dari total pendapatan Koperasi Wanita Kiblat Praya maka sebesar Rp 38,09,- akan terserap dalam biaya operasional koperasi. Jika dilihat dari rata-rata total biaya-biaya maka dapat disimpulkan bahwa Koperasi Wanita Kiblat Praya memiliki biaya operasional yang lebih besar dibandingakan dengan Koperasi Wanita Kartini Praya.

3) Sisa Hasil Usaha

Koperasi Wanita Kartini Praya memiliki nilai rata-rata SHU sebesar 68,91\% dari total pendapatannya, sedangkan Koperasi Wanita Kiblat Praya memiliki nilai ratarata total SHU sebesar $60,96 \%$ dari total pendapatannya. Hal ini berarti bahwa setiap Rp 100,- total pendapatan Koperasi Wanita Kartini Praya akan mengahasilkan SHU bersih sebesar Rp 68,91,- dan setiap Rp 100,- total pendapatan Koperasi Wanita Kiblat Praya akan mengahasilkan SHU bersih sebesar Rp 60,96,-. Jika dilihat dari rata-rata total SHU maka dapat disimpulkan bahwa Koperasi Wanita Kartini Praya memiliki SHU yang lebih besar dibandingakan dengan Koperasi Wanita Kiblat Praya. 


\section{Kesimpulan}

\section{KESIMPULAN DAN SARAN}

\section{a. Koperasi Wanita Kartini Praya}

\section{1) Analisis Rasio}

Koperasi Wanita Kartini Praya berada dalam kondisi yang sangat baik disetiap rasio keuangannya. Hal ini ditunjukkan dari kriteria disetiap rasio keuangannya yang menunjukkan bahwa rasio keuangan dimilki berada pada kriteria tertinggi disetiap kriteria rasionya. Kecuali pada rasio likuiditas, dimana rasio likuditas Koperasi Wanita Kartini Praya berada dalam kondisi tidak likuid selama tahun penelitian

\section{1) Analisis Trend}

Trend dari setiap rasio keuangan yang dimiliki oleh Koperasi Wanita Kartini Praya berada pada kondisi yang beragam yaitu pada kondisi cenderung meningkat, cenderung meningkat dan menurun, dan cenderung menurun. Adapun trend rasio yang cenderung mengalami peningkatan diantaranya adalah trend rasio modal sendiri terhadapa total aset, trend rasio likuiditas, dan trend rasio kemandirian operasional. Trend rasio yang cenderung mengalami peningkatan dan penurunan adalah trend rasio rentabilitas aset dan trend rasio rentabilitas modal sendiri, dan trend rasio yang cenderung mengalami penurunan diantaranya adalah trend rasio efisiensi dan trend rasio aktiva tetap terhadap total aset.

\section{2) Analisis Common Size}

Koperasi Wanita Kartini Praya menunjukkan kinerja keuangan yang baik. Perubahan pada pos-pos laporan keuangannya lebih banyak menunjukkan peningkatan khususnya pada nilai SHU yang merupakan hasil akhir dalam kegiatan usaha yang dijalankan pada periode tahun 2010-2014.

\section{b. Koperasi Wanita Kiblat Praya}

1) Analisis Rasio

Rasio keuangan Koperasi Wanita Kiblat Praya memiliki kondisi yang beragam yaitu berada. Untuk beberapa rasio berada dalam kondisi yang sangat baik diantaranya adalah rasio modal sensiri terhdapa total aset, rasio efisiensi, rasio aktiva tetap terhadap total modal, rasio rentabilitas modal sendiri, danrasio kemandirian operasional. Rasio yang berada dalam kondisi cukup baik adalah rasio rentabilitas aset, karena secara rata-rata berada pada kriteria cukup. Sedangkan untuk rasio lakuiditas berada dalam kondisi tidak likuid selama tahun penelitian.

\section{2) Analisis Trend}

Trend dari setiap rasio keuangan yang dimiliki oleh Koperasi Wanita Kiblat Praya berada pada kondisi yang beragam yaitu pada kondisi cenderung meningkat, cenderung meningkat dan menurun, dan cenderung menurun. Adapun trend rasio yang cenderung mengalami peningkatan diantaranya adalah trend rasio modal sendiri terhadap total aset dan trend rasio likuiditas. Trend rasio yang cenderung mengalami peningkatan dan penurunan adalah Trend rasio efisiensi, trend rasio rentabilitas aset, trend rasio rentabilitas modal sendiri, dan trend rasio kemandirian operasional. Sedangkan trend rasio yang cenderung mengalami penurunan adalah trend rasio aktiva tetap terhadap total aset.

\section{3) Analisis Common Size}

Koperasi Wanita Kartini Praya menunjukkan kinerja keuangan yang masih kurag baik. Perubahan pada pos-pos laporan keuangannya lebih banyak menunjukkan peningkatan dan penurunan khususnya pada nilai SHU yang merupakan hasil akhir dalam kegiatan usaha yang dijalankan pada periode tahun 2010-2014. 


\section{c. Perbandingan Koperasi Wanita Kartini Praya dengan Koperasi Wanita Kiblat Praya \\ 1) Analisis Rasio}

Koperasi Wanita Kartini Praya dan Koperasi Wanita Kiblat Praya memiliki kemampuan yang sama baiknya dalam beberapa hal diantaranya adalah: (1) kemampuan dalam menghimpun modal sendiri terhadap total modal yang dimiliki, (2) efisiensi dalam memberikan pelayanan kepada anggota dari penggunaa aset yang dimilki (3) peningkatan aktiva dari total aset yang dimiliki, (4) pemenuhan hutang jangka pendek, (5) menghasilkan laba dari total modal sendiri (6) dan kemampuan dalam mengelola kegiatan usahanya. Sedangkan dalam menghasilkan laba terhadap total asetnya, Koperasi Wanita Kartini Praya memiliki kemampuan yang lebiih baik dari Koperasi Wanita Kiblat Praya.

\section{2) Analsis Trend}

Dari hasil perbandingan analisis trend Koperasi Wanita Kartini dan Koperasi Wanita Kiblat Praya maka dapat disimpulkan bahwa memiki kesamaan trend yang cenderung meningkat dalam (1) trend rasio modal sendiri terhadap total aset, dan (2) trend rasio likuiditas. Trend rasio koperasi wanita kartini praya dan koperasi Wanita Kiblat Praya memiki kesamaan trend yang cenderung menurun dalam trend rasio aktiva tetap terhadap total aset. Trend koperasi wanita kartini Praya dan Koperasi Wanita Kiblat Praya memiiki kesamaan trend yang cenderung mengalami peningkatan dan penurunan dalam (1) trend rasio rentabilitas aset, (2) trend rentabilitas moda sendiri. Pada trend efisiensi diketahui bahwa Koperasi Wanita Kartini Praya memiki trend yang cendreung menurun sedangkan Koperasi Wanita Kiblat Praya cenderung mengalami penaikan dan penurunan. Pada trend rasio kemandirian operasional pelayanan diketahui bahwa Koperasi Wanita Kartini Praya memiliki trend yang cenderung peningkatan sedangkan Koperasi Wanita Kiblat Praya cenderung mengalami peningkatan dan penurunan.

\section{3) Analisis Common Size}

Berdasarkan hasil anasis data dan pembahasan yang telah dilakukan sebelumnya maka dapat disimpulkan bahwa: (1) Koperasi Wanita Kartini Praya memiliki investasi yang lebih besar dibandingakan dengan Koperasi Wanita Kiblat Praya dalam bentuk aktiva lancar. (2) Koperasi Wanita Kiblat Praya memiliki investasi yang lebih besar dibandingakan dengan Koperasi Wanita Kartini Praya dalam bentuk aktiva tetap.(3) Koperasi Wanita Kiblat Praya memiliki pembiayaan pasiva dari kewajiban lancar yang lebih besar dibandingakan dengan Koperasi Wanita Kartini Praya. (4) Koperasi Wanita Kartini Praya memiliki pembiayaan pasiva dari kekayaan bersih yang lebih besar dibandingakan dengan Koperasi Wanita Kiblat Praya. (5) Koperasi Wanita Kiblat Praya memiliki pendapatan lebih besar dibandingakan dengan Koperasi Wanita Kartini Praya. (6) Koperasi Wanita Kiblat Praya memiliki biaya operasional yang lebih besar dibandingakan dengan Koperasi Wanita Kartini Praya. (7) Koperasi Wanita Kartini Praya memiliki SHU yang lebih besar dibandingakan dengan Koperasi Wanita Kiblat Praya.

\section{Saran}

Adapun saran yang dapat diberikan dalam perbaikan dan peningkatan kinerja lebih lanjut bagi Koperasi Wanita Kartini Praya dan Koperasi Wanita Kiblat Praya maupun bagi peneliti yang ingin melakukan penelitian mengenai kinerja keuangan, yaitu sebagai berikut:

\section{a. Bagi peneliti}

Bagi peneliti diharapkan dapat melakukan penelitian dengan lebih baik dari pada penelitian ini yaitu, dengan menambah faktor-faktor yang dapat mendukung penelitiannya menjadi lebih baik. Faktor-faktor tersebut seperti memperpanjang tahun penelitian (semakin panjang tahun penelitian maka hasilnya semakin baik), menambah jumlah variabel rasio keuangan yang mewakili penelitian selanjutnya dan lain-lain. 


\section{b. Bagi Koperasi Wanita Kartini Praya dan Koperasi Wanita Kiblat Praya}

Memaksimalkan usaha koperasi dengan memberikan pelayanan yang prima bagi anggota khususnya dan masyarakat pada umumnya karena keberhasilan koperasi berarti kesejahteraan bagi anggotanya. Koperasi juga lebih dianjurkan untuk mengefisienkan dalam mengalokasikan sumber daya yang dimiliki sehingga dapat menekan biaya operasional yang ada. Selain peningkatan kinerja keuangan, aspek-aspek manajemen juga perlu diperhatikan misalnya jumlah anggota serta partisipasinya dalam kegiatan koperasi.

\section{DAFTAR PUSTAKA}

Jumingan, 2006. Analisis Laporan Keuangan. Jakarta: PT Bumi Aksara

Munawir. 1996. Analisis Laporan Keuangan. Liberty: Yogyakarta.

Munawir. 2004. Akuntansi Keuangan dan Manajmen. BPFE: Yogyakarta.

Munawir. 2005. Akuntansi Keuangan dan Manajmen. BPFE: Yogyakarta.

Sudarsono \& Edilius. 2004. Manajemen Koperasi Indonesia. Jakarta: Rineka. Cipta

Sutrisno. 2008. Manajemen Keuangan Teori, Konsep dan Aplikasi. Yogyakarta: Ekonisia.

Wild, John 2005. General Accounting. Jakarta: Penada Media Group. 